\title{
MCT1 and MCT4 Kinetic of mRNA Expression in Different Tissues After Aerobic Exercise at Maximal Lactate Steady State Workload
}

\author{
G. G. DE ARAUJO ${ }^{1,2}$, C. A. GOBATTO ${ }^{1}$,F. DE BARROS MANCHADO-GOBATTO ${ }^{1}$, \\ L. F. M. TEIXEIRA ${ }^{3}$, I. G. M. DOS REIS ${ }^{1}$, L. C. CAPERUTO ${ }^{4}$, M. PAPOTI $^{5}$, S. BORDIN $^{4}$, \\ C. R. CAVAGLIERI ${ }^{3}$, R. VERLENGIA ${ }^{3}$ \\ ${ }^{1}$ Laboratory of Sport Applied Physiology, School of Applied Science, Campinas State University \\ (UNICAMP), Limeira, Sao Paulo, Brazil, ${ }^{2}$ Sports Science Research Group, Physical Education \\ (CEDU) and Post Graduation in Nutrition, Federal University of Alagoas (UFAL), Maceio, \\ Alagoas, Brazil, ${ }^{3}$ Physical Education, Faculty of Sciences of Health, Methodist University of \\ Piracicaba, Piracicaba, Sao Paulo, Brazil, ${ }^{4}$ Department of Physiology and Biophysics, Institute of \\ Biomedical Sciences, University of Sao Paulo (USP), Sao Paulo, Sao Paulo, Brazil, ${ }^{5}$ Physical \\ Education School of Ribeirão Preto, University of Sao Paulo (USP), Sao Paulo, Sao Paulo, Brazil
}

Received November 5, 2013

Accepted September 15, 2014

On-line December 3, 2014

\section{Summary}

We evaluate the mRNA expression of monocarboxylate transporters 1 and 4 (MCT1 and MCT4) in skeletal muscle (soleus, red and white gastrocnemius), heart and liver tissues in mice submitted to a single bout of swimming exercise at the maximal lactate steady state workload (MLSSw). After $72 \mathrm{~h}$ of MLSS test, the animals were submitted to a swimming exercise session for $25 \mathrm{~min}$ at individual MLSSw. Tissues and muscle samples were obtained at rest (control, $n=5$ ), immediately $(n=5)$, $5 \mathrm{~h}(n=5)$ and $10 \mathrm{~h}(n=5)$ after exercise for determination of the MCT1 and MCT4 mRNA expression (RT-PCR). The MCT1 mRNA expression in liver increased after $10 \mathrm{~h}$ in relation to the control, immediate and $5 \mathrm{~h}$ groups, but the MCT4 remained unchanged. The MCT1 mRNA expression in heart increased by $31 \%$ after $10 \mathrm{~h}$ when compared to immediate, but no differences were observed in relation to the control group. No significant differences were observed for red gastrocnemius in MCT1 and MCT4 mRNA expression. However, white gastrocnemius increased MCT1 mRNA expression immediately when compared to rest, 5 and $10 \mathrm{~h}$ test groups. In soleus muscle, the MCT1 mRNA expression increased immediately, 5 and $10 \mathrm{~h}$ after exercise when compared to the control. In relation to MCT4 mRNA expression, the soleus increased immediately and $10 \mathrm{~h}$ after acute exercise when compared to the control group. The soleus, liver and heart were the main tissues that showed improved the MCT1 mRNA expression, indicating its important role in controlling MLSS concentration in mice.

\section{Key words}

Gene Expression • Swimming • Mice • Lactate

\section{Corresponding author}

G. G. de Araujo, Federal University of Alagoas, Sports Science Research Group, Post Graduation in Nutrition - Department of Physical Education/CEDU, Avenue Lourival Melo Mota, District of Tabuleiro dos Martins, Postal number: 57072-900, Maceio, Alagoas, Brazil. E-mail: gusta_ef@yahoo.com.br

\section{Introduction}

The sarcolemmal lactate/proton cotransporter is controlled by monocarboxylate transporters (MCT) 1 and 4. MCT1 is mainly present in oxidative muscle fibers and has been associated with lactate/proton influx and intracellular oxidation (Thomas et al. 2004, 2005). Although high $K m$, MCT4 is not correlated with fast fiber type and is characterized by large inter-individual variation (Dimmer et al. 2000, Thomas et al. 2012). Studies indicate that MCT1 (but not MCT4) contributes to increased metabolic use of lactate during and after muscle activity (Bonen et al. 1998, Dubouchaud et al. 
2000). However, the roles of both MCT1 and MCT4 intracellular signals in endurance intensity are still uncertain, since most studies about these transporters have been conducted after high intensity exercise and associated high lactate production (Bickhan et al. 2006, Burgomaster et al. 2007, Bishop et al. 2007, 2008).

The Maximal Lactate Steady State (MLSS) is defined as the highest blood lactate concentration and workload that can be maintained over time without continual blood lactate accumulation. MLSS workload is considered the 'gold standard' marker of aerobic capacity (Gobatto et al. 2001, Ferreira et al. 2007). Among the methods used for the development of aerobic adaptations, training prescription at MLSS workload is one of the most adequate (de Araujo et al. 2007). The lactate equilibrium (between 2-8 $\mathrm{mmol} / \mathrm{l}$ ) during exercise at MLSS workload allows a maximum reaction rate $(\mathrm{Km})$ of MCT1 (Billat et al. 2003). When oxidative capacity of muscles is increased by endurance exercise, the mRNA expression of MCT1 is also increased (Bonen et al. 2000). However, the contribution of MCT1 and MCT4 on different tissues and muscles on lactate equilibrium in MLSS workload has not yet been demonstrated.

Although there has been increasing interest in the scientific basis of intensity determination using the MLSS protocol, we still lack the necessary degree of MCTs specificity to regulate the lactate steady-state. Furthermore, it is not clear what are the main tissues and muscles involved in lactatemia equilibrium as well as participation of MCT1 and MCT4 at MLSS workload. Since most of the training sessions for laboratory rats and human beings (i.e., trained and untrained) are performed near the MLSS intensity (Gobatto et al. 2001, Ferreira et al. 2007, Seiler and Kjerland 2006), a better understanding MCT1 and MCT4 responses at MLSS workload may provide valuable insights for several areas of research.

In order to investigate the kinetics of MCT1 and MCT4 mRNA expression in different tissues in response to endurance exercise, we examined the effect of a single bout of swimming exercise at MLSS workload on the gene expression in skeletal muscles (soleus, red and white gastrocnemius), heart and liver of laboratory mice. Specifically, we hypothesized that single effort at MLSS workload increases the kinetic MCT1 (but not MCT4) mRNA expression in oxidative tissues and muscles in order to regulate the MLSS.

\section{Materials and Methods}

Animals

All experiments involving the animals were performed in accordance to the specific Brazilian resolutions on the Bioethics in Experiments with animals (no 93/08, approved in September $9^{\text {th }}, 2008$ ), that is in agreement to the guidelines of the Guide to the Care and Use of Experimental Animals for research involving animals.

Male C57BL/6J mice were used in all experiments $(n=20)$. The animals were housed in a room with a light cycle from 06:00 am to $6: 00 \mathrm{pm}$, at $22 \pm 2{ }^{\circ} \mathrm{C}$ and it were fed a commercial rodent chow and water $a d$ libitum. All experiments were preceded by 2 weeks of individual adaptation to the deep water $\left(31 \pm 1^{\circ} \mathrm{C}\right)$ environment consisting of 5 min water exposure daily, 5 days a week, in cylindrical tanks $(80 \mathrm{~cm}$ diameter $\times$ $120 \mathrm{~cm}$ depth), subdivided into cylindrical compartments of $30 \mathrm{~cm}$ diameter $\times 120 \mathrm{~cm}$ depth for individual swimming (de Araujo et al. 2007).

\section{Maximal lactate steady state (MLSS)}

For MLSS determination, 20 mice were submitted to $25 \mathrm{~min}$ of swimming, performed continuously with loads equivalent to 3, 4, 5, 6 and $7 \%$ of the body weight and blood samples $(25 \mu \mathrm{l}$ collected by the tail) collection each $5 \mathrm{~min}$. This procedure occurred in alternated days and the loads were applied randomly. The MLSS was assumed as the highest exercise intensity in which blood lactate elevation did not exceed $1 \mathrm{mmol} / \mathrm{l}$ between the $10^{\text {th }}$ and $25^{\text {th }}$ min of exercise (Gobatto et al. 2001, Billat et al. 2003, Manchado et al. 2005).

\section{Blood samples and analysis}

During the tests, blood samples $(25 \mu \mathrm{l})$ were placed in tubes with capacity to $1.5 \mathrm{ml}$ containing $50 \mu \mathrm{l}$ of sodium fluoride $(1 \%)$. Blood lactate concentrations were determined in a lactate analyzer (YSI 1500 Sport, Yellow Springs, USA).

Acute exercise at MLSS workload (MLSSw) and sample tissues

After $72 \mathrm{~h}$ of MLSS determination, 15 mice were selected randomly to swim 25 min continuously at individual MLSSw. The animals were randomly assigned in 3 groups (5 mice for groups) and euthanized at different times to obtain the muscles and tissues samples: immediately (I); $5 \mathrm{~h}$ and $10 \mathrm{~h}$ after acute exercise at 
MLSSw. The control group (C) was composed by 5 mice that were submitted to MLSS protocol but not performed the acute exercise in order to be sacrificed in rest.

The liver, heart, soleus, red gastrocnemius and white gastrocnemius samples were collected for measurement of MCT1 and MCT4 mRNA expression. The animals were euthanized with $20 \%$ chloralhydrate (0.3 $\mathrm{ml} \mathrm{x} 100 \mathrm{~g}^{-1}$ animal weight) for tissues excision (liver, soleus, heart, red and white gastrocnemius). The tissues were carefully dissected in sterilized place and then placed into autoclaved tubes. As a consequence, the tubes were inserted immediately in liquid nitrogen $\left(-190^{\circ} \mathrm{C}\right)$.

\section{MCT1 and MCT4 MRNA expression}

The gene expression was determinated by semiquantitative analysis using RT-PCR. Total RNA was extracted using TRIZOL (Invitrogen Life Technologies, Carlsbad, CA) as described by manufacturer instructions. Briefly, tissue was homogenized (Polytron, PT-MR 2100, Luzern, Switzerland) with $1 \mathrm{ml}$ Trizol reagent (Life Technologies, Rockville, MD, USA). After $5 \mathrm{~min}$ of incubation at room temperature, $200 \mu$ l chloroform were added to the tubes and centrifuged at $12000 \mathrm{xg}$. The aqueous phase was transferred to another tube and the RNA was pelleted by centrifugation $(12000 \mathrm{xg})$ with cold ethanol and dried in air. RNA pellets were diluted in RNase-free water and stored at $-70{ }^{\circ} \mathrm{C}$ until the time of the experiment. The RNA was quantified by measuring absorbance at $260 \mathrm{~nm}$. The purity of the RNAs was assessed by the $260 / 280 \mathrm{~nm}$ ratio and on a $1 \%$ agarose gel stained with ethidium bromide at $0.5 \mu \mathrm{g} / \mathrm{ml}$ (Sambrook and Russell 2001). These samples were used for RT-PCR analysis.

\section{$R T-P C R$}

The sequences of the primers were designed using information contained public database in GeneBank of the National Center for Biotechnology Information (NCBI Reference Sequence: NM_009196.4 for MCT1 and NM_030696.3 for MCT4). The RT-PCR was performed using parameters described by Verlengia et al. (2004). The number of cycles used was selected to allow quantitative comparison of the samples in a linear way (Verlengia et al. 2004). The reaction conditions of PCR annealing temperature and PCR fragment lengths for each gene and tissues are shown in the Table 1. For the semiquantitative analysis, the housekeeping $\beta$-actin gene was used as reference (Rafalski et al. 2007). Published guidelines were followed to guard against bacterial and nucleic acid contamination (Kwok and Higuchi 1989).

Table 1. The standardized conditions for RT-PCR analysis.

\begin{tabular}{|c|c|c|c|c|c|c|}
\hline Gene & $\begin{array}{c}\text { Sense } \\
\text { primer }\end{array}$ & $\begin{array}{l}\text { Antisense } \\
\text { primer }\end{array}$ & $\begin{array}{c}\text { Annealing } \\
\text { temperature }\left({ }^{\circ} \mathrm{C}\right)\end{array}$ & $\begin{array}{l}\text { PCR fragment } \\
\text { lengths (bp) }\end{array}$ & Tissues & $\begin{array}{c}\text { Amplification } \\
\text { cycles }\end{array}$ \\
\hline \multirow{5}{*}{ MCT1 } & & & \multirow{5}{*}{57.1} & \multirow{5}{*}{254} & $\mathrm{H}$ & 34 \\
\hline & 5'-GTG ACC & 5'-GTC TCC & & & $\mathrm{L}$ & 32 \\
\hline & ATT GTG GAA & TTT GGC TTC & & & $\mathrm{RG}$ & 34 \\
\hline & TGC TGC-3’ & TCG TCG-3’ & & & WG & 35 \\
\hline & & & & & $\mathrm{S}$ & 37 \\
\hline \multirow{5}{*}{ MCT4 } & & & \multirow{5}{*}{58.2} & \multirow{5}{*}{291} & $\mathrm{H}$ & 34 \\
\hline & 5'-TGC CAT & 5’-TCT GCC & & & $\mathrm{L}$ & 37 \\
\hline & TGG TCT CGT & TTC AGG AAG & & & $\mathrm{RG}$ & 34 \\
\hline & GCT G-3' & TGC TCC-3’ & & & WG & 34 \\
\hline & & & & & $\mathrm{S}$ & 37 \\
\hline \multirow{5}{*}{$\beta$-actin } & & & \multirow{5}{*}{58.2} & \multirow{5}{*}{205} & $\mathrm{H}$ & 30 \\
\hline & 5'-ACA GGC & 5'-TGT CAC & & & $\mathrm{L}$ & 34 \\
\hline & ATT GTC ATG & CGA TTT CCC & & & $\mathrm{RG}$ & 32 \\
\hline & GAC TCC G-3' & & & & WG & 32 \\
\hline & & & & & $\mathrm{S}$ & 34 \\
\hline
\end{tabular}

The sequences of the primers, the PCR fragment lengths, the temperature and the number of cycles are shown for each gene and tissues ( $\mathrm{H}=$ heart; $\mathrm{L}=$ liver; $\mathrm{RG}=$ red gastrocnemius; $\mathrm{WG}=$ white gastrocnemius; $\mathrm{S}=$ soleus) under study. 


\section{Analysis of the PCR products}

The analysis of PCR amplification products was performed in $1.5 \%$ agarose gel containing $0.5 \mu \mathrm{g} / \mathrm{ml}$ ethidium bromide and electrophoresed for $1 \mathrm{~h}$ at $100 \mathrm{~V}$. The gels were visualized using an ultraviolet light in Chemi System (UVP Biolmaging systems, Uppsala, Sweden) and photographed using a $\operatorname{Kodak}^{\circledast}$ Digital Science DC120 Zoom Digital Camera (Gibco-BRL, Life Technologies, Inc., Gaithersburg, MD, EUA). The images were processed and analyzed in the software Kodak Digital Science 1 D Image Analysis (Gibico-BRL, Life Technologies, Inc., Gaithersburg, MD, EUA). PCR band intensities were expressed as OD normalized for $\beta$ actin expression. The data are presented as the ratio with respective controls, which received an arbitrary value of 1 in each experiment.

\section{Statistical analysis}

The results are presented as mean \pm standard error (SEM). One-way ANOVA was used to compare the MCT1 and MCT4 mRNA expression values obtained immediately, 5 and $10 \mathrm{~h}$ after acute exercise at MLSSw. When necessary, Tukey post-hoc test was applied. Individual relationships between variables were studied by means of linear regressions using Excel ${ }^{\circledR}$ software. Effect sizes were determined by the formula: $\left[\mathrm{mean}_{1}-\right.$ mean $\left._{2}\right]$ /pooled SD for the differences of variables. In all statistical analysis the significant level was set at $\mathrm{P}<0.05$ (Statistica $7 \cdot 0^{\circledR}$ ).

\section{Results}

\section{Maximal lactate steady state}

The mice had MLSS concentrations of 5.00 to $6.00 \mathrm{mmol} / \mathrm{l}$ at a workload between $3-5 \%$ of body weight (Fig. 1).

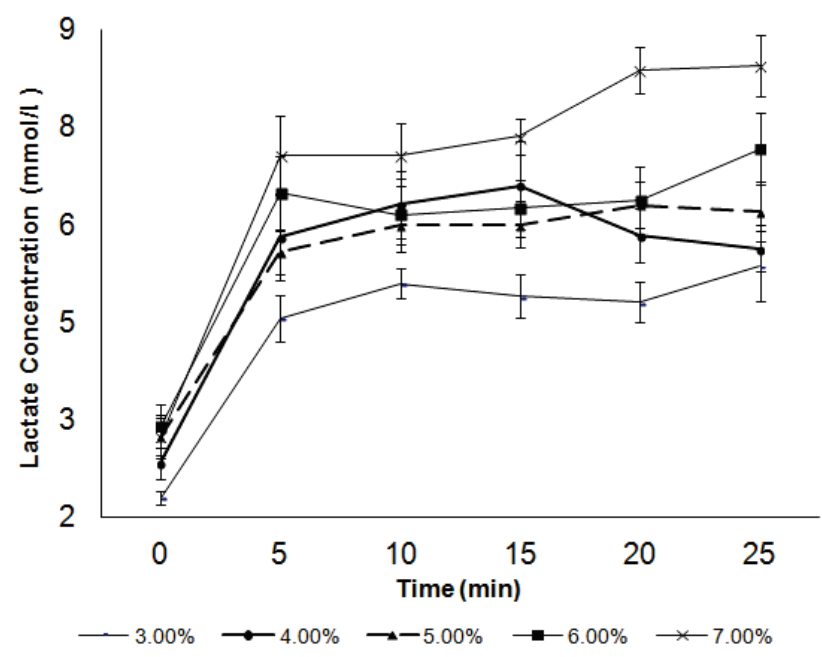

Fig. 1. Maximal lactate steady state (MLSS) determination in sedentary mice. The MLSS determination used randomized loads of $3.00,4.00,5.00,6.00$ and $7.00 \%$ of body weight. The MLSS was considered as the maximal overload that shows lactate stabilization between the $10^{\text {th }}$ and $25^{\text {th }}$ min of exercise. The results are presented as mean \pm SEM.

MCT1 mRNA expression in different tissues after acute swimming exercise in the MLSSW

MCT1 mRNA expression in heart, liver, red gastrocnemius, white gastrocnemius and soleus are presented in Figure 2 and Figure 3. The MCT1 mRNA expression in heart tissue increased $31 \%$ after $10 \mathrm{~h}$ when compared to immediate $(\mathrm{I})$ period $($ effect size $=1.71)$, but no differences were observed in relation to the control (C) group (effect size $=0.56)($ Fig. 2). In liver tissue, MCT1 mRNA expression after $10 \mathrm{~h}$ was 39,35 and $37 \%$ higher than the C, I and $5 \mathrm{~h}$ groups, respectively (Fig. 2).

No differences in MCT1 were observed for red gastrocnemius muscle after acute exercise at MLSSw in relation to the Control (Fig. 3). However, a significant increase in MCT1 mRNA expression was observed in white gastrocnemius muscle immediately after exercise in
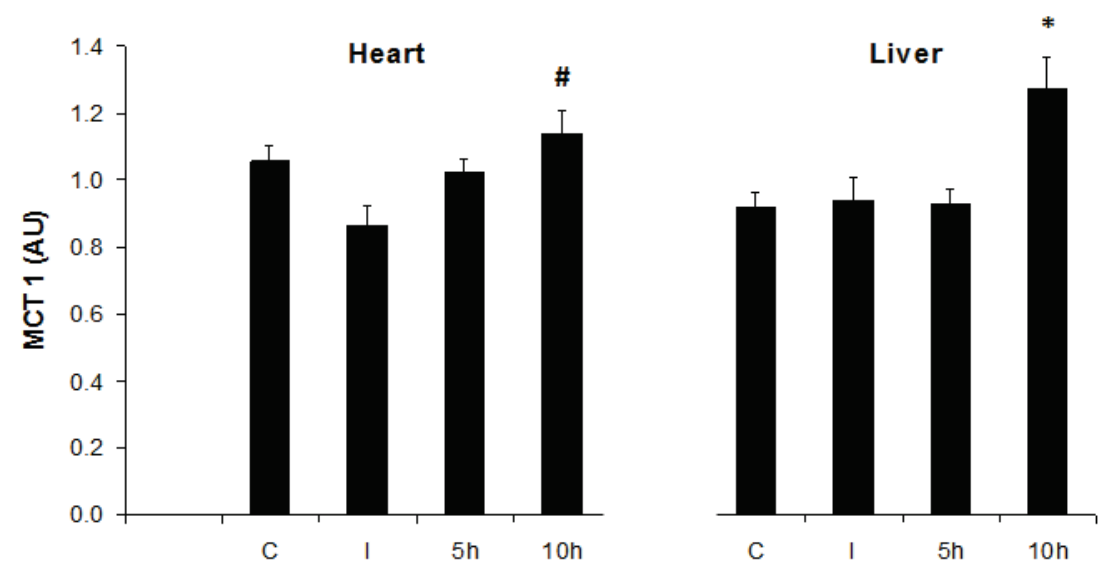

Fig. 2. Effect of the swimming exercise in the MLSS intensity (25 $\mathrm{min}$ ) on the gene expression of the MCT1 in heart and liver obtained immediately (I), 5 and $10 \mathrm{~h}$ after the exercise. Data are reported as the mean \pm SEM of 6 experiments performed in duplicate. "Significantly different in relation to immediately (I); * Significantly different from all the groups 

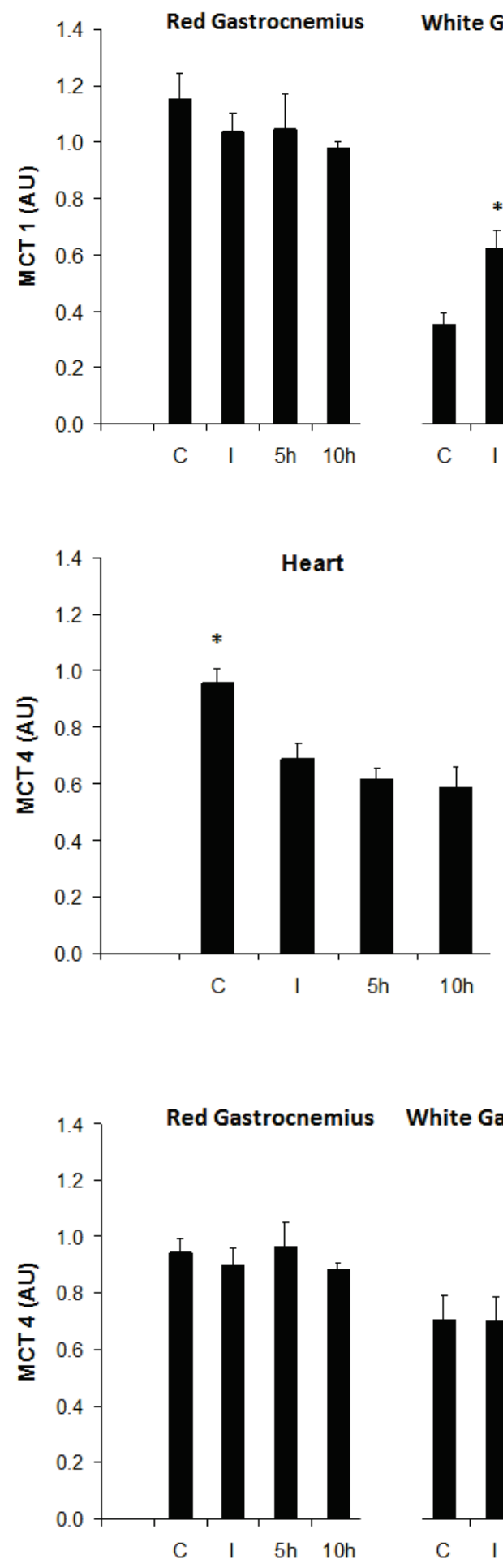

White Gastrocnemius

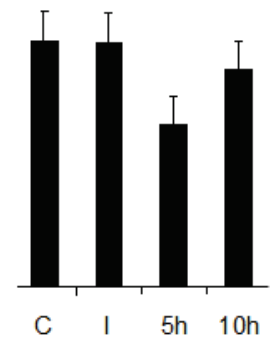

comparison to control $(62 \%$, effect size $=2.08), 5 \mathrm{~h}$ $(61 \%$, effect size $=3.49)$ and $10 \mathrm{~h}(57 \%$, effect size $=$ 3.35) test groups (Fig. 3). MCT1 mRNA expression in soleus muscle increased in the immediate $(202 \%), 5 \mathrm{~h}$ $(227 \%)$ and $10 \mathrm{~h}(230 \%)$ group when compared to the control group (Fig. 3).

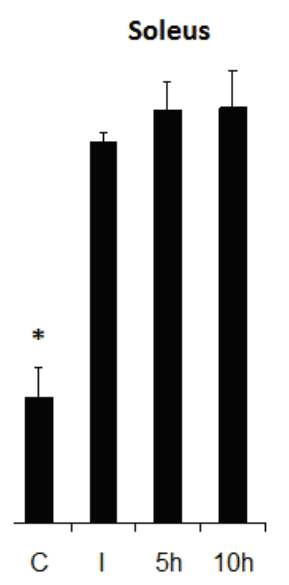

Liver

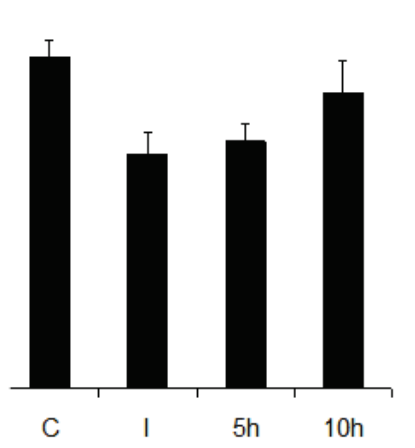

Soleus

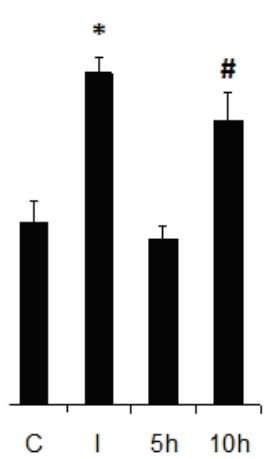

Fig. 3. Effect of the swimming exercise in the MLSS intensity $(25 \mathrm{~min})$ on the gene expression of the MCT1 in red gastrocnemius, white gastrocnemius and soleus obtained immediately (I), 5 and $10 \mathrm{~h}$ after the exercise. Data are reported as the mean \pm SEM of 6 experiments performed in duplicate. * Significantly different from all the groups
Fig. 4. Effect of the swimming exercise in the MLSS intensity (25 $\mathrm{min})$ on the gene expression of the MCT4 in heart and liver obtained immediately (I), 5 and $10 \mathrm{~h}$ after the exercise. Data are reported as the mean \pm SEM of 6 experiments performed in duplicate. * Significantly different from all the groups
Fig. 5. Effect of the swimming exercise in the MLSS intensity (25 $\mathrm{min}$ ) on the gene expression of the MCT4 in red gastrocnemius, white gastrocnemius and soleus obtained immediately (I), 5 and $10 \mathrm{~h}$ after the exercise. Data are reported as the mean \pm SEM of 6 experiments performed in duplicate. ${ }^{\#}$ Significantly different in relation to control (C); * Significantly different from all the groups
MCT4 mRNA expression in different tissues after acute swimming exercise in the MLSSw

MCT4 mRNA expressions in heart, liver red gastrocnemius, white gastrocnemius and soleus are presented in Figure 4 and Figure 5. MCT4 mRNA expression in heart tissue reduced $28 \%$ (immediately); $35 \%$ (after $5 \mathrm{~h}$ ) and $38 \%$ (after $10 \mathrm{~h}$ ) compared with control group (Fig. 4). Conversely, there were no 
observed differences in MCT4 mRNA expression between treatments and control in liver tissue (Fig. 4).

Likewise, no differences were observed between treatment and control groups in red gastrocnemius and white gastrocnemius muscles (Fig. 5). However, in soleus muscle there was an immediate increase of $82 \%$ and a $56 \%$ increase $10 \mathrm{~h}$ after acute exercise in comparison to the control group (Fig. 5).

\section{Relationships between variables}

In heart tissue, MCT1 mRNA expression was positively correlated with the MLSS workload ( $r=0.89$, $n=5) 10 \mathrm{~h}$ after acute exercise. The MLSS concentration was positively correlated with MCT1 $10 \mathrm{~h}$ after acute exercise in white gastrocnemius muscle $(r=0.91, n=5)$. There were no significant correlations observed for the other tissues and muscles used in the study.

\section{Discussion}

To the best of our knowledge, this is the first study to investigate MCT1 and MCT4 mRNA expression in numerous tissues and muscles under conditions of MLSS workload. MLSS has been considered the gold standard protocol to evaluate the aerobic capacity (Beneke et al. 2000, Billat et al. 2003). Billat et al. (2003) defined MLSS as the highest blood lactate concentration and workload that is maintained over time without continual blood lactate accumulation. Thus, the investigation of MCT1 and MCT4 mRNA expression during a MLSS test provides clear insights for understanding the mechanisms of lactate equilibrium.

The first step of this study was to determine MLSS in mice using a swimming exercise. Despite using an adapted protocol (Gobatto et al. 2001, Ferreira et al. 2007), the observed values of MLSS concentration were similar to those found in humans (Beneke 1995, Billat et al. 2003) and running rats (Manchado et al. 2005). Specifically, an MLSS concentration of $\sim 4.00 \mathrm{mmol} / 1$ has been recorded in both humans and running Wistar rats (Pilis et al. 1993, Manchado et al. 2005, Faude et al. 2009). In Wistar rats submitted to swimming, the MLSS concentration was $\sim 5.50 \mathrm{mmol} / \mathrm{l}$ (Pilis et al. 1993, Gobatto et al. 2001, de Araujo et al. 2007). However, during running the lactate MLSS concentration was lower in mice $(3.00 \mathrm{mmol} / \mathrm{l})$ than Wistar rats submitted to the same protocol (Ferreira et al. 2007). These results indicate that MLSS concentration is both ergometer and species dependent. Thus, measurement of the MCT kinetic of mRNA expression in other studies could be an effective means to elucidate these differences among mice, rats, humans and ergometers.

As hypothesized, our results indicate significantly higher MCT1 mRNA expression in liver, heart and soleus muscle as compared to MCT4 mRNA expression $10 \mathrm{~h}$ after endurance exercise (at MLSSw). The metabolic state of the tissues or the availability of substrate as metabolic fuel seems influence the level of mRNA and protein expression, and may involve both transcriptional and post-transcriptional mechanisms (Enerson and Drewes 2003, Philp et al. 2005).

Previous studies have indicated that MCT1 (but not MCT4) protein expression is related to the increase the aerobic capacity and uptake of lactate in skeletal muscle after endurance interventions (Bonen et al. 2000, Benton et al. 2008). Benton et al. (2008) applied a chronic electric stimulation (12 Hz, $24 \mathrm{~h}$ /day, 7 days) in different muscle tissues (i.e., soleus, red and white gastrocnemius) to simulate an endurance muscle contraction, recording a positive relationship between PGC-1alpha protein and MCT1 protein expression as well as an increase the rate of lactate uptake into muscle. This data suggests that PGC-1alpha is a key co-activator of selected transcription factors that induce an oxidative phenotype in skeletal muscles. It is important to note that none of these experiments detected an association between MCT4 expression and PGC-1alpha.

The control mechanisms of MCT4 expression are still poorly understood. It is thought that the hypoxiainducible factor-1 (HIF-1) contributes to MCT4 upregulation by hypoxia as observed in other components of the glycolytic metabolism (Ullah et al. 2006). Lindholm et al. (2014) reported a significant negative regulation of HIF-1 in elite cyclists and triathletes in relation to moderately active men after 6 weeks of an endurance training program (four $45 \mathrm{~min}$ sessions per week at $70 \%$ of $\mathrm{VO}_{2}$ peak). HIF activity influences muscle metabolism and leads to increased lactate accumulation and reduced muscle $\mathrm{pH}$ in response to exercise. The results of these studies suggest that negative regulation of HIF-1 mediates the attenuation of PDK-1 and contributes to skeletal muscle aerobic adaptation to endurance exercise. Moreover, RIP140 could be a likely candidate for regulating MCT4 based on its inverse relationship with the oxidative capacity (Seth et al. 2007). In the context of our study, this may mean a predominance of aerobic metabolism during MLSS workload. Probably, the lower lactate/proton efflux at MLSS intensity in comparison to 
high intensity exercise is not sufficient to signal the MCT4 in oxidative muscle (Pilegaard et al. 1999, Bonen et al. 2000, Yoshida et al. 2004).

Our results indicate that liver tissue and soleus muscle experienced an increase in MCT1 mRNA expression $10 \mathrm{~h}$ after acute exercise at MLSS workload in relation to the control group, indicating its role in controlling MLSS concentration (Coles et al. 2004). Billat et al. (2003) argues that lactate clearance is primarily through oxidation in active muscle tissue. Thus, the MCT1 mRNA expression in soleus muscle indicates that an active slow-twitch oxidative fiber may be important for lactate oxidation and, by extension, control of MLSS concentration (Roy et al. 1991, Bonen et al. 2000, Dubouchaud et al. 2000, Bonen 2001).

In relation to liver tissue, MLSS workload was important to increase the MCT1 mRNA expression $10 \mathrm{~h}$ after exercise. It is well known that hepatocytes are important for gluconeogenesis in order to control lactate influx during moderate intensity exercise (Messonnier et al. 2007). Our results support this interpretation, indicating that the main function of hepatocytes during MLSS is to improve the lactate influx and consequently glucose efflux (Halestrap et al. 1997, Halestrap and Meredith 2004, Messonnier et al. 2007). However, this process appears to be more related to MCT1 than MCT4 mRNA expression. Thus, the liver is important for lactate clearance during MLSS as indicated by the increase in MCT1 mRNA expression $10 \mathrm{~h}$ after exercise (Billat et al. 2003).

MCT1 mRNA expression in heart tissue was not altered after exercise when compared with control. This result may be attributed to high signaling and endogenous levels of MCT1 protein in the myocardium because it is a specialized organ for lactate oxidation (Bonen et al. 2006). The high correlation between MLSS workload and MCT1 mRNA expression in heart $10 \mathrm{~h}$ after exercise $(r=0.89)$ is interesting, and may indicate a predisposition to aerobic capacity in mice with enhanced MCT1 expression in heart tissue. The MCT4 mRNA expression decreased in heart tissue $10 \mathrm{~h}$ after exercise. Differences in abundance and sub-cellular distribution of MCT1 and MCT4 in rat heart tissue were described by Bonen et al. (2000), who reported that MCT4 mRNA expression is barely detectable and MCT4 protein appears to be absent (Bonen et al. 2000). In contrast, both MCT4 mRNA and MCT4 protein are detectable in human heart tissue (Price et al. 1998, Wilson et al. 1998). This indicates abundant species level variation in MCT4 expression, though there is no comparable data on MCT4 mRNA expression in mice.

Contrary to our hypothesis, MCT1 gene expression in white gastrocnemius muscle increased immediately after the endurance exercise. Considering that MCT1 mRNA expression is highly controlled by acidosis level, the lactate concentration in MLSS $(5.50 \mathrm{mmol} / \mathrm{l})$ may indicate adaptations in gene expression independent of fiber type due to $K m$ between 3.00-5.00 mmol/1 (Tonouchi et al. 2002). Our data support the existence of such adaptations since the MLSS concentration was correlated with MCT1 $10 \mathrm{~h}$ after exercise in white gastrocnemius muscle $(\mathrm{r}=0.91)$. Also, these data agree with the results of Coles et al. (2004) using a treadmill, which demonstrated that the muscles with the lowest MCT1 content (i.e., white gastrocnemius) and MCT4 content (i.e., soleus) have the greatest relative signaling of MCT1 and MCT4, respectively. This response is related with the principle of expression-rapid induction (Hildebrandt et al. 2003).

In comparison to the control group, acute exercise did not induce adaptations in red gastrocnemius, since MTC1 and MCT4 remained unchanged after acute exercise. However, the absence of changes in red gastrocnemius in relation control group does not indicate that the tissue is not important to MLSS concentration and further studies are clearly needed to better understand the intracellular signaling in muscle.

Our results have implications for experimental research that uses physical exercise to understand the metabolism/substrate regulation with different interventions (i.e., pathologies, nutrition, drugs and other) and, more specifically, for studies with human beings that aim to establish reference values in relation to MCTs kinetic of mRNA expression during endurance exercise. It appears that MCT1 mRNA expression is regulated by MLSS concentration in predominantly oxidative tissues such as the soleus muscle, liver and heart. In white gastrocnemius muscle, the MLSS workload increased MCT1 mRNA expression immediately after exercise. However, exercise at MLSS workload did not increase MCT4 mRNA expression in oxidative tissues (liver and heart) and soleus muscle. Further studies are now required to investigate protein concentrations in tissues since there seems to be no direct correlation between protein and mRNA levels in mammalian cells (PradetBalade et al. 2001). 


\section{Conflict of Interest}

There is no conflict of interest.

\section{Acknowledgements}

This research is supported by FAPESP (04/06643-1), CAPES, CNPq and FAP-UNIMEP.

\section{References}

BENEKE R: Anaerobic threshold, individual anaerobic threshold, and maximal lactate steady state in rowing. Med Sci Sports Exerc 27: 863-867, 1995.

BENEKE R, HUTLER M, LITHAUSER RM: Maximal lactate-steady-state independent of performance. Med Sci Sports Exerc 32: 1135-1139, 2000.

BENTON CR, YOSHIDA Y, LALLY J, HAN XX, HATTA H, BONEN A: PGC-1alpha increases skeletal muscle lactate uptake by increasing the expression of MCT1 but not MCT2 or MCT4. Physiol Genomics 35: 45-54, 2008.

BICKHAM DC, BENTLEY DJ, LE ROSSIGNOL PF, CAMERON-SMITH D: The effects of short-term sprint training on MCT expression in moderately endurance-trained runners. Eur J Appl Physiol 96: 636-643, 2006.

BILLAT VL, SIRVENT P, PY G, KORALSZTEIN JP, MERCIER J: The concept of maximal lactate steady state: a bridge between biochemistry, physiology and sport science. Sports Med 33: 407-426, 2003.

BISHOP D, EDGE J, THOMAS C, MERCIER J. High-intensity exercise acutely decreases the membrane content of MCT1 and MCT4 and buffer capacity in human skeletal muscle. J Appl Physiol 102: 616-21, 2007.

BISHOP D, EDGE J, THOMAS C, MERCIER J: Effects of high-intensity training on muscle lactate transporters and postexercise recovery of muscle lactate and hydrogen ions in women. Am J Physiol Regul Integr Comp Physiol 295: R1991-R1998, 2008.

BONEN A: The expression of lactate transporters (MCT1 and MCT4) in heart and muscle. Eur J Appl Physiol 86: 6-11, 2001.

BONEN A, MCCULLAGH KJ, PUTMAN CT, HULTMAN E, JONES NL, HEIGENHAUSER GJ: Short-term training increases human muscle MCT1 and femoral venous lactate in relation to muscle lactate. Am J Physiol 274: E102-E107, 1998.

BONEN A, TONOUCHI M, MISKOVIC D, HEDDLE C, HEIKKILA JJ, HALESTRAP AP: Isoform-specific regulation of the lactate transporters MCT1 and MCT4 by contractile activity. Am J Physiol Endocrinol Metab 279: E1131-E1138, 2000.

BONEN A, HEYNEN M, HATTA H: Distribution of monocarboxylate transporters MCT1-MCT8 in rat tissues and human skeletal muscle. Appl Physiol Nutr Metab 31: 31-39, 2006.

BURGOMASTER KA, CERMAK NM, PHILLIPS SM, BENTON CR, BONEN A, GIBALA MJ: Divergent response of metabolite transport proteins in human skeletal muscle after sprint interval training and detraining. Am J Physiol Regul Integr Comp Physiol 292: R1970-R1976, 2007.

COLES L, LITT J, HATTA H, BONEN A: Exercise rapidly increases expression of the monocarboxylate transporters MCT1 and MCT4 in rat muscles. J Physiol 561: 253-261, 2004.

DE ARAUJO GG, PAPOTI M, MANCHADO FB, MELLO MA, GOBATTO CA: Protocols for hyperlactatemia induction in the lactate minimum test adapted to swimming rats. Comp Biochem Physiol A Mol Integr Physiol 148: 888-892, 2007.

DIMMER KS, FRIEDRICH B, LANG F, DEITMER JW, BRÖER S: The low-affinity monocarboxylate transporter MCT4 is adapted to the export of lactate in highly glycolytic cells. Biochem J 15: 219-227, 2000.

DUBOUCHAUD H, BUTTERFIELD GE, WOLFEL EE, BERGMAN BC, BROOKS GA: Endurance training, expression, and physiology of LDH, MCT1, and MCT4 in human skeletal muscle. Am J Physiol Endocrinol Metab 278: E571-E579, 2000.

ENERSON BE, DREWES LR: Molecular features, regulation, and function of monocarboxylate transporters: implications for drug delivery. J Pharm Sci 92: 1531-1544, 2003.

FAUDE O, KINDERMANN W, MEYER T: Lactate threshold concepts: how valid are they? Sports Med 39: 469-490, 2009. 
FERREIRA JCB, ROLIM NPL, BARTHOLOMEU JB, GOBATTO CA, KOKUBUN E, BRUM PC: Maximal lactate steady state in running mice: effects of exercise training. Clin Exp Pharmacol Physiol 34: 760-765, 2007.

GOBATTO CA, MELlO MAR, SIBUYA CY, AZEVEDO JRM, SANTOS LA, KOKUBUN E: Maximal lactate steady state in rats submitted to swimming exercise. Comp Biochem Physiol A Mol Integr Physiol 130: 21-27, 2001.

HALESTRAP AP, MEREDITH D: The SLC16 gene family-from monocarboxylate transporters (MCTs) to aromatic amino acid transporters and beyond. Pflügers Archiv Eur Journal Appl Physiol 447: 619-628, 2004.

HALESTRAP AP, WANG X, POOLE RC, JACKSON VN, PRICE NT: Lactate transport in heart in relation to myocardial ischemia. Am J Cardiol 4: 17-25, 1997.

HILDEBRANDT AL, PILEGAARD H, NEUFER PD: Differential transcriptional activation of select metabolic genes in response to variations in exercise intensity and duration. Am J Physiol Endocrinol Metab 285: E1021E1027, 2003.

KWOK S, HIGUCHI R: Avoiding false positives with PCR. Nature 339: 237-238, 1989.

MANCHADO FB, GOBATTO CA, CONTARTEZE RVL, PAPOTI M, MELLO MAR: Maximal lactate steady state in running rats. $J$ Exerc Physiol online 8: 29-35, 2005.

MESSONNIER L, KRISTENSEN M, JUEL C, DENIS C: Importance of $\mathrm{pH}$ regulation and lactate/ $\mathrm{H}^{+}$transport capacity for work production during supramaximal exercise in humans. J Appl Physiol 102: 1936-1944, 2007.

PHILP A, MACDONALD AL, WATT PW: Lactate - a signal coordinating cell and systemic function. J Exp Biol 208: 4561-4575, 2005.

PILEGAARD H, DOMINO K, NOLAND T, JUEL C, HELLSTEN Y, HALESTRAP AP, BANGSBO J: Effect of high-intensity exercise training on lactate $/ \mathrm{H}^{+}$transport capacity in human skeletal muscle. Am J Physiol Endocrinol Metab 276: E255-E261, 1999.

PILIS W, ZARZECZNY R, LANGFORT J, KACIUBA-USCILKO H, NAZAR K, WOJTYNA J: Anaerobic threshold in rats. Comp Biochem Physiol A Mol Integr Physiol 106: 285-289, 1993.

PRADET-BALADE B, BOULMÉ F, BEUG H, MÜLLNER EW, GARCIA-SANZ JA: Translation control: bridging the gap between genomics and proteomics? Trends Biochem Sci 26: 225-229, 2001.

PRICE NT, JACKSON VN, HALESTRAP AP: Cloning and sequencing of four new mammalian monocarboxylate transporter (MCT) homologues confirms the existence of a transporter family with an ancient past. Biochem J 15: 321-328, 1998.

RAFALSKI K, ABDOURAHMAN A, EDWARDS JG: Early adaptations to training: upregulation of alpha-myosin heavy chain gene expression. Med Sci Sports Exerc 39: 75-82, 2007.

ROY JY, BONGBELE J, CARDIN S, BRISSON GR, LAVOIE JM: Effects of supramaximal exercise on blood glucose levels during a subsequent exercise. Eur J Appl Physiol 63: 48-51, 1991.

SAMBROOK J, RUSSELL DW: Molecular Cloning: A Laboratory Manual, 3rd ed. Cold Spring Harbor Laboratory Press, Cold Spring Harbor (NY), 2001.

SEILER KS, KJERLAND GØ: Quantifying training intensity distribution in elite endurance athletes: is there evidence for an "optimal" distribution? Scand J Med Sci Sports 16: 49-56, 2006.

SETH A, STEEL JH, NICHOL D, POCOCK V, KUMARAN MK, FRITAH A, MOBBERLEY M, RYDER TA, ROWLERSON A, SCOTT J, POUTANEN M, WHITE R, PARKER M: The transcriptional corepressor RIP140 regulates oxidative metabolism in skeletal muscle. Cell Metab 6: 236-245, 2007.

THOMAS C, SIRVENT P, PERREY S, RAYNAUD E, MERCIER J: Relationships between maximal muscle oxidative capacity and blood lactate removal after supramaximal exercise and fatigue indexes in humans. $J$ Appl Physiol 97: 2132-2138, 2004.

THOMAS C, PERREY S, LAMBERT K, HUGON G, MORNET D, MERCIER J: Monocarboxylate transporters, blood lactate removal after supramaximal exercise, and fatigue indexes in humans. J Appl Physiol 98: 804-809, 2005.

THOMAS C, BISHOP DJ, LAMBERT K, MERCIER J, BROOKS GA: Effects of acute and chronic exercise on sarcolemmal MCT1 and MCT4 contents in human skeletal muscles: current status. Am J Physiol Regul Integr Comp Physiol 302: R1-R14, 2012. 
TONOUCHI M, HATTA H, BONEN A: Muscle contraction increases lactate transport while reducing sarcolemmal MCT4, but not MCT1. Am J Physiol Endocrinol Metab 282: E1062-E1069, 2002.

ULLAH MS, DAVIES AJ, HALESTRAP AP: The plasma membrane lactate transporter MCT4, but not MCT1, is upregulated by hypoxia through a HIF-1 $\alpha$-dependent mechanism. J Biol Chem 281: 9030-9037, 2006.

VERLENGIA R, GORJÃO R, KANUNFRE CC, BORDIN S, MARTINS DE, LIMA T, CURI R: Comparative effects of eicosapentaenoic acid and docosahexaenoic acid on proliferation, cytokine production, and pleiotropic gene expression in Jurkat cells. J Nutr Biochem 15: 657-665, 2004.

WILSON MC, JACKSON VN, HEDDLE C, PRICE NT, PILEGAARD H, JUEL C, BONEN A, MONTGOMERY I, HUTTER OF, HALESTRAP AP: Lactic acid efflux from white skeletal muscle is catalyzed by the monocarboxylate transporter isoform MCT3. J Biol Chem 26: 15920-15926, 1998.

YOSHIDA Y, HATTA H, KATO M, ENOKI T, KATO H, BONEN A: Relationship between skeletal muscle MCT1 and accumulated exercise during voluntary wheel running. J Appl Physiol 97: 527-534, 2004. 